\title{
ANALISIS GAYA KEPEMIMPINAN DALAM MEMBENTUK KARAKTERISTIK BUDAYA ORGANISASI (STUDI PENELITIAN PADA SMA NEGERI DI KABUPATEN BANJAR)
}

\author{
Esthi Endah Ayuningtyas \\ Pascasarjana Manajemen Pendidikan \\ Universitas Islam Kalimantan Muhammad Arsyad Al Banjari \\ esthiendah12@gmail.com/085288886712
}

\begin{abstract}
ABSTRAK
Penelitian ini bertujuan untuk mengetahui dan menganalisa Gaya Kepemimpinan Dalam Membentuk Karakteristik Budaya Organisasi (Studi Penelitian Pada SMA Negeri Di Kabupaten Banjar). Penelitian ini menggunakan metode analisa data kuantitatif, teknik analisis yang Dalam penelitian ini, metode analisis data yang digunakan adalah regresi linier sederhana yaitu permodelan persamaan regresi. Alasan pemilihan menggunakan metode regresi linier sederhana ini adalah disesuaikan dengan tujuan penelitian ini yaitu untuk menguji pengaruh variabel independen terhadap variabel terikat. Hasil analisis yang dilakukan menyatakan bahwa Gaya Kepemimpinan berpengaruh signifikan terhadap Karakteristik Budaya Organisasi Pada SMA Negeri Di Kabupaten Banjar. Dengan demikian membuktikan Gaya Kepemimpinan dapat meningkatkan dalam pembentukan Karakteristik Budaya Organisasi Pada SMA Negeri Di Kabupaten Banjar
\end{abstract}

Kata Kunci : Gaya Kepemimpinan, Karakteristik Budaya Organisasi

\begin{abstract}
This study aims to identify and analyze leadership styles in shaping organizational culture characteristics (research studies at public high schools in Banjar district). This study uses quantitative data analysis methods, analytical techniques. In this study, the data analysis method used is simple linear regression, namely regression equation modeling. The reason for choosing using this simple linear regression method is adjusted to the purpose of this study, namely to examine the effect of the independent variable on the dependent variable. The results of the analysis conducted state that the leadership style has a significant effect on the Characteristics of Organizational Culture at Public Senior High Schools in Banjar Regency. Thus proving that the Leadership Style can improve the formation of the Characteristics of Organizational Culture in Public Senior High Schools in Banjar Regency.
\end{abstract}

Keywords: Leadership Style, Characteristics of Organizational Culture 


\section{PENDAHULUAN}

Guru diposisikan sebagai garda depan dan posisi sentral di dalam pelaksananan proses pendidikan. Kritik yang diberikan terhadap guru baik positif maupun negatif akan menjadi masukan yang sangat berarti bagi kinerja guru. Dalam satuan pendidikan, guru memiliki peran yang sangat menentukan dalam proses pembelajaran di sekolah. Tidak hanya sebagai pendidik, namun juga sebagai pengajar, pelatih, dan pembimbing.

Guru cenderung tidak memperdulikan kondisi psikologis yang terjadi pada siswa di kala proses belajar mengajar berlangsung karena mengejar target kurikulum. Hal ini dilakukan oleh guru karena takut dimarahi oleh kepala sekolah, bila target kurikulum belum tercapai. Ada juga guru (untuk mata pelajaran tertentu) yang malas memeriksa hasil ulangan siswa karena kepala sekolah telah menginstruksikan batas minimum nilai yang harus dimasukkan ke dalam buku rapot. Guru rtersebut beranggapan bahwa untuk apa diperiksa, toh nilainya juga sudah ada patokannya. Adanya patokan nilai seperti ini akan memberikan peluang kepada guru untuk memanipulasi nilai. Sudah tentulah kondisi dan tindakan seperti ini tidak memenuhi kriteria keprofesionalan. Dengan kata lain ia tidak bertindak secara profesional sebagai seorang guru. Dengan demikian, harus diakui bahwa masih ada guru di lapangan yang belum atau kurang profesional. Dan hal inilah yang selalu disorot oleh masyarakat. Oleh karena itu, diperlikan cara dan tempat untuk mengembangkan profesi guru.

Manusia baik secara individu, dalam kelompok, dan organisasi memiliki naluri untuk dikenal oleh manusia lainnya atau lingkungannya. Oleh karena itu, manusia akan selalu berusaha melakukan sesuatu yang berbeda, baik dalam sikap ataupun perilaku yang khas maupun dalam bentuk hasil karya tertentu. Perilaku tertentu atau hasil karya tersebut akan menjelma menjadi identitas dan citra manusia, baik secara individu, kelompok organisasi, bahkan komunitas masyarakat terentu. Robbins dan Coulter (2010) mengemukakan bahwa, "budaya organisasi atau organizational culture adalah sehimpunan nilai, prinsip, tradisi, dan cara bekerja yang dianut bersama yang mempengaruhi perilaku serta tindakan para anggota organisasi”. Dalam kebanyakan organisasi, nilai-nilai dan praktik-praktik yang dianut Bersama ini telah berkembang pesat seiring dengan perkembangan zaman dan benar-benar sangat mempengaruhi bagaimana sebuah organisasi dijalankan

Budaya organisasi merupakan salah satu terbentuknya gaya kepemimpinan. Kepemimpinan merupakan kemampuan, seni dan proses. Hal ini dapat mengacu pada suatu kegiatan atau aktivitas yang harus dilakukan untuk memengaruhi orang lain supaya berperilaku tertentu. Seni berarti cara, metode, atau strategi yang dapat mempengaruhi untuk mendapatkan kepengikutan (Badeni, 2014). Menurut (Latif, 2008) ketrampilan yang digunakan oleh seorang pemimpin agar para perawat-perawat terpengaruh dalam pengawasan pembagian tigas dan tanggung jawab mengenai pemberian pelayanan asuhan keperawatan, sehingga akan tercapainya tujuan pada keperawatan merupakan kepemimpinan dalam keperawatan. Perilaku tentang kepemimpinan dapat terlihat dari gaya kepemimpinannya yang muncul ketika seseorang memimpin bawahanya. Gaya kepemimpinan yang efektif sangat diperlukan karena dapat mempengaruhi kinerja bawahaan. Pemimpin mempunyai pengaruh besar terhadap keberhasilan organisasi, menurut Kuezes \& Posner (2010). Mondy (1990) dalam Soetopo (2010) budaya kelompok atau organisasi secara menyakinkan dipengaruhi gaya kepemimpinan (leadership style).

Sikap seperti ini akan menimbulkan dampak negatif terhadap organisasi apabila pemimpin menjaga jarak (aloof) dengan bawahan. Wirawan (2007), budaya organisasi yang dikenal dengan perilaku dan sikap yang dimiliki individu dalam bekerja sama agar dapat tercapai. Budaya organisasi dapat mempengaruhi pada perilaku anggota organisasi yang kemudian akan menentukan kinerja anggota dan organisasi. Pemimpin dari organisasi dapat menambahkan, mengembangkan, dan merubah sesuai dengan kepemimpinannya didalam organisasi. Maka dari itu, adanya hubungan antara kepemimpinan dan budaya organisasi karena tidak ada pemimpin yang terlepas dari budaya organisasinya (Robbins \& Coulter, 2010). Studi yang dilakukan oleh Tsang dkk (2007), budaya organisasi kuat dengan adanya peran pemimpin, budaya organisasi akan semakin kuat apabila nilai kepemimpinan tinggi. Perlu adanya seorang pemimpin untuk memperlihatkan dan memikirkan sebuah gaya kepemimpinan yang nantinya akan diterapkan kepada pegawainya yang terdapat di dalam kepemimpinan (Mulyadi \& Rivai, 2008). Norma perilaku orang tersebut dapat digunakan pada orang lain saat orang itu ingin mempengaruhi perilakunnya dari orang lain tersebut yaitu merupakan dalam gaya kepemimpinan (Handoko, 2010). Rivai (2007), mengatakan kesuksesan pegawai dalam berprestasi dapat dipengaruhi oleh gaya kepemimpinan atasan.

\section{METODE \\ Jenis Penelitian}

Jenis penelitian ini termasuk dalam jenis penelitian yang bersifat eksplanasi ilmu dapat digolongkan pada jenis penelitian kausalitas yaitu penelitian yang ingin mencari penjelasan dalam bentuk hubungan sebab akibat (cause-effect) antar beberapa konsep atau beberapa variable atau beberapa strategi 
yang dikembangkan dalam manajemen dan diarahkan untuk menggambarkan adanya sebab akibat antara beberapa situasi yang digambarkan dalam variable, dan atas dasar itu ditariklah sebuah kesimpulan umum (Ferdinand, 2014).

\section{Subjek Penelitian}

Moleong (2010: 132) mendeskripsikan subjek penelitian sebagai informan, yang artinya orang pada latar penelitian yang dimanfaatkan untuk memberikan informasi tentang situasi dan kondisi latar penelitian. Subjek pada penelitian ini adalah pelanggan SMA Negeri Di Kabupaten Banjar

\section{Teknik Pengumpulan Data}

Adapun teknik pengumpulan data dalam hasil penelitian ini yaitu sebagai berikut:

a. Kuesioner, yaitu dengan cara menyampaikan kuisioner kepada responden untuk mendapatkan data sesuai dengan tujuan penelitian. Penelitian ini menggunakan skala likert, beberapa pertanyaan diurutkan secara hierarkis untuk melihat sikap tertentu dari sederetan itu. Jadi skala likert adalah skala yang digunakan untuk jawaban yang bersikap jelas (tegas).

b. Observasi, yaitu teknik pengumpulan data yang dilakukan dengan cara mengamati langsung ke obyek penelitian.

c. Dokumentasi dan Studi Pustaka, yaitu teknik pengumpulan data yang dilakukan dengan mempelajari literatur maupun dokumen dari obyek penelitian

\section{Teknik Analisa Data}

Penelitian ini menggunakan metode analisa data kuantitatif, teknik analisis yang Dalam penelitian ini, metode analisis data yang digunakan adalah regresi linier sederhana yaitu permodelan persamaan regresi. Alasan pemilihan menggunakan metode regresi linier sederhana ini adalah disesuaikan dengan tujuan penelitian ini yaitu untuk menguji pengaruh variabel independen terhadap variabel terikat

\section{HASIL DAN PEMBAHASAN}

\section{Analisis Regresi}

Hasil output dari SPSS 23 terhadap data skor yang telah dibuat berdasarkan jawaban responden dari kuisioner yang telah dibagikan, kemudian dirangkum menjadi bahasan-bahasan sebagaimana yang terlihat pada Tabel berikut:

Sumber: Data Primer diolah (2020)

Secara matematis model fungsi regresi linear berganda dapat dinyatakan sebagai berikut :

$\mathrm{Y}=4.024+0,598 \cdot \mathrm{x}+\mathrm{e}$

Interpretasi persamaan tersebut adalah sebagai berikut: Peningkatan terhadap variabel Gaya Kepemimpinan sebesar 0,598 adalah positif, yang berarti bahwa adanya hubungan searah antara variabel bebas dan variabel terikat, semakin meningkat nilai pada Gaya Kepemimpinan, maka hubungan dalam Membentuk Karakteristik Budaya Organisasi Pada SMA Negeri Di Kabupaten Banjar juga akan meningkat sebesar 59,8\%

\section{Uji Koefisien Determinasi}

Koefisien determinasi diuraikan model summary statistik, yang antara lain adalah sebagai berikut:

$$
\text { Table } 2
$$

\begin{tabular}{|c|c|c|c|c|}
\hline Model & $\mathrm{R}$ & $\begin{array}{c}\mathrm{R} \\
\text { Square }\end{array}$ & $\begin{array}{c}\text { Adjusted R } \\
\text { Square }\end{array}$ & $\begin{array}{l}\text { Std. Error } \\
\text { of the } \\
\text { Estimate }\end{array}$ \\
\hline 1 & $.925^{\mathrm{a}}$ & .855 & .853 & 2.10322 \\
\hline
\end{tabular}

Sumber: Data Primer diolah (2020).

Nilai R dengan nilai sebesar 0,925 atau $92,5 \%$ adalah koefisien korelasi yang menunjukkan tingkat hubungan antara variabel Gaya Kepemimpinan dengan variabel Membentuk Karakteristik Budaya Organisasi Pada SMA Negeri Di Kabupaten Banjar Nilai korelasi tersebut menunjukkan tingkat hubungan sangat kuat karena berada di antara 0,600 sampai dengan 0,799.

Tabel 3

Tabulasi Interprestasi Nilai $\mathbf{r}$

\begin{tabular}{|c|c|c|}
\hline No & Interval Koefisien & Tingkat Hubungan \\
\hline 1 & $0,800-1,000$ & Sangat Kuat \\
\hline 2 & $0,600-0,799$ & Kuat \\
\hline 3 & $0,400-0,599$ & Sedang \\
\hline 4 & $0,200-0,399$ & Rendah \\
\hline 5 & $0,000-0,199$ & Sangat Rendah \\
\hline
\end{tabular}

\section{Hasil Pengujian Hipotesis}

Uji $\mathrm{t}$ ini bertujuan untuk mengetahui ada tidaknya pengaruh variabel $\mathrm{X}$ terhadap terhadap $\mathrm{Y}$. Adapun hasil pengujian sebagai berikut :

Tabel 4

Hasil Uji-t

\begin{tabular}{|c|c|c|c|c|c|}
\hline \multirow[t]{2}{*}{ Model } & \multicolumn{2}{|c|}{$\begin{array}{c}\text { Unstandardized } \\
\text { Coefficients }\end{array}$} & $\begin{array}{l}\text { Standardized } \\
\text { Coefficients }\end{array}$ & \multirow[t]{2}{*}{$t$} & \multirow[t]{2}{*}{ Sig. } \\
\hline & B & Std. Error & Beta & & \\
\hline (Constant & 4.024 & 1.800 & & 2.236 & .029 \\
\hline $\mathrm{x}$ & .598 & .032 & .925 & 18.513 & .000 \\
\hline
\end{tabular}

Tabel 1

Hasil Pengolahan Data

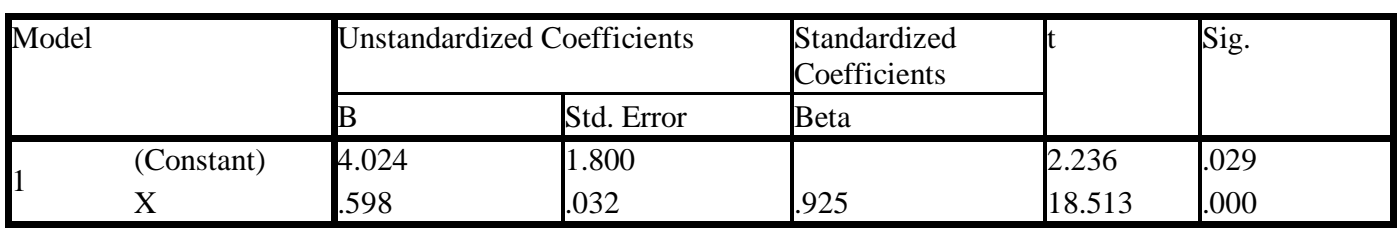


Berdasarkan hasil pengujian yang tercantum pada tabel diatas dapat dilihat bahwa: Variabel Gaya Kepemimpinan didapatkan nilai sig. $=0.000$ (Nilai Sig. <), dengan demikian dapat diketahui variabel Gaya Kepemimpinan berpengaruh signifikan terhadap variabel terikat Budaya Organisasi.

\section{Pembahasan Hasil Penelitian}

Berdasarkan hasil penelitian di ketahui didapatkan nilai sig. $=0.000$ (Nilai Sig. $>0,05$ ) artinya Gaya Kepemimpinan berpengaruh signifikan terhadap Karakteristik Budaya Organisasi Pada SMA Negeri Di Kabupaten Banjar. Dengan demikian membuktikan Gaya Kepemimpinan dapat meningkatkan dalam pembentukan Karakteristik Budaya Organisasi Pada SMA Negeri Di Kabupaten Banjar.

Beberapa faktor yang dapat mempengaruhi tugas dari seorang pemimpin: kematangan, kecerdasan, motivasi dan hubungan manusiawi. Menurut Bachtiar (2009), Gaya kepemimpinan adalah rancangan dapat tercapai suatu organisasi dengan ditujukan pada individu agar dapat tercapainya. Gaya kepemimpinan bisa mempengaruhi kepribadian dalam gaya yang digunakan. Menurut Nursalam (2011), gaya kepemimpinan demokratis adalah cara yang dilakukan oleh seorang pemimpin untuk mencapai tujuan yang sudah direncanakan. Menurut Kuntoro (2010), gaya kepemimpinan demokratis pemberian tanggungjawab dan pengambilan keputusan dengan melibatkan kelompok pegawai. Pemimpin mampu menghargai setiap karakteristik dalam kemampuan pegawai serta dapat digunakanya jawabannya untuk memperoleh ideide para pegawainya dapat meningkat.

Menurut Robbins (2010), budaya organisasi adalah yang mempengaruhi cara bawahan bertindak dengan yang diharapkan dari pegawai yaitu dapat memahami nilai pokok organisasi secara jelas dan mampu mengetahuinya agar dapat bertindak secara cepat. Berdasarkan hasil analisa hubungan antara gaya kepemimpinan dengan budaya organisasi di SMA Negeri Di Kabupaten Banjar menunjukan bahwa dari hasil diperoleh nilai $p$ value 0.000 lebih kecil dari 0,05 sehingga dapat disimpulkan gaya kepemimpian berpengaruh signifikan terhadap karakteristik karakteristik budaya organsasi, Arah korelasi ini yaitu posistif yang berarti bahwa gaya kepemimpinan yang semakin baik akan meningkatkan karakteristik budaya organsasi.

Berdasarkan nilai korelasi menurut Sugiyono (2010) bahwa nilai koefisien korelasi sebesar 0,925 atau $92,5 \%$ adalah koefisien korelasi yang menunjukkan tingkat hubungan antara variabel Gaya Kepemimpinan dengan variabel Membentuk Karakteristik Budaya Organisasi Pada SMA Negeri Di Kabupaten Banjar Nilai korelasi tersebut menunjukkan tingkat hubungan sangat kuat karena berada di antara 0,600 sampai dengan 0,799. Kepemimpinan sangatlah penting karena mempunyai pengaruh akan menciptakan kepercayaan dan ketaatan, sehingga mampu melaksanakan tugas secara efektif dan efisien.

\section{PENUTUP}

Gaya Kepemimpinan berpengaruh signifikan terhadap Karakteristik Budaya Organisasi Pada SMA Negeri Di Kabupaten Banjar. Dengan demikian membuktikan Gaya Kepemimpinan dapat meningkatkan dalam pembentukan Karakteristik Budaya Organisasi Pada SMA Negeri Di Kabupaten Banjar. Berdasarkam hasil penelitian diatas dengan melihat indikator dari variabel yang ada, maka saransaran yang dapat disampaikan sebagai berikut:

1. Bagi peneliti selanjutnya untuk menambah jumlah responden lebih besar dari jumlah yang peneliti lakukan, dengan tujuan mampu menyerap pendapat responden lebih luas lagi

2. Bagi SMA Negeri di Kabupaten Banjar Dapat memfokuskan perhatian antara pimpinan dan bawahan dengan komunikasi lebih insentif agar Guru SMA Negeri di Kabupaten Banjar mampu memiliki komitmen yang tinggi yang akan berdampak pada kesadaran kinerja.

3. Ciptakan suasana kerja yang lebih harmonis, dan nyaman bagi seluruh Guru SMA Negeri di Kabupaten Banjar, sehingga diharapkan Guru SMA Negeri di Kabupaten Banjar mampu peduli terhadap pekerjaan yang belum terselesaikan sesama rekan kerja

4. Diharapkan Kepala Sekolah SMA Negeri di Kabupaten Banjar lebih memberikan pendekatanpendekatan yang lebih menyenangkan, dan juga memberikan kegiatan-kegiatan yang menarik kepada Guru SMA Negeri di Kabupaten Banjar, sehingga para guru akan merasa di hargai, kemudian dapat meningkatkan karakteristik budaya organisasi SMA Negeri di Kabupaten Banjar

5. SMA Negeri di Kabupaten Banjar sebaiknya membuat suatu peraturan yang disepakati bersama dimana setiap Guru SMA Negeri di Kabupaten Banjar wajib mengajarkan kemampuan yang dimiliki kepada rekan kerjanya agar menciptakan lingkungan kerja yang harmonis.

6. Memberi kesempatan bagi anggota organisasi khususnya Guru SMA Negeri di Kabupaten Banjar untuk mengembangkan ide dalam penyelesaian masalah dalam pekerjaan, bahwa di lingkungan kerja antar rekan kerja bukan lagi aset melainkan mitra kerja, yang aspirasinya perlu dihargai 


\section{REFERENSI}

Abdul Latif. 2009 Pendidikan Berbasis Nilai Kemanusiaan, Bandung: Refika Aditama

Alwi, Syafaruddin. (2010). Manajemen Sumber Daya Manusia Strategi Keunggulan Kompetitif. Yogyakarta: BPFE

Badeni. 2014. Kepemimpinan dan Perilaku Organisasi. Bandung: Alfabeta

Ferdinand, Augusty. 2014. Metode Penelitian Manajemen. BP Universitas Diponegoro. Semarang

Handoko, T. Hani. (2010). Manajemen Personalia \& Sumber daya Manusia. BPFE-Yogyakarta

Hutapea, Parulian dan Nurianna Thoha, 2008, Kompetensi Plus : Teori, Desain, Kasus dan Penerapan untuk HR dan Organisasi yang Dinamis, Penerbit : Gramedia Pustaka Utama, Jakarta

Kaila, Dr.H.L. (2005). Human Resource Management (In Two Volumes). India

Koesmono, H. Teman (2005) Pengaruh Budaya Organisasi Terhadap Motivasi dan Kepuasan Kerja serta Kinerja Karyawan Pada Sub Sektor Industri Pengolahan Kayu Skala Menengah Di Jawa Timur

Kouzes, James \& Posner. (2010). The Leadership Challenge. San Francisco: Jossey-Bass

Makmuri, Muchlas. 2005. Perilaku Organisasi, Gadjah Mada University Press, Yogyakarta

Mulyadi dan Rivai (2008) Manajemen Sumber Daya Manusia, Jakarta cetakan kesembilan

Moleong, Lexy J. (2010), Metodologi penelitian kualitatif, Remaja Rosdakarya, Bandung

Richard West, Lynn H.Turner. 2008 Pengantar Teori Komunikasi: Analisis dan Aplikasi (Buku 2) (Edisi 3) Jakarta: Salemba Humanika

Robbins, P. Stephen. (2003). Perilaku Organisasi. Edisi Sembilan, Jilid 2. Edisi Bahasa Indonesia. PT Indeks Kelompok Gramedia, Jakarta
Robbins, Stephen P. dan Coulter, Mary. 2010. Manajemen Edisi Kesepuluh. Jakarta: penerbit Erlangga

Robbins, P.Stephen dan Timothy A. Judge. 2012. Perilaku Organisasi. Salemba Empat. Jakarta

Soetopo, Hendyat. 2010. Perilaku Organisasi. Jakarta: PT. Remaja Rosdakarya

Veithzal Rivai. (2007). Bank and Financial Institute Management. Jakarta: PT. Raja GrafindoPersada

Wirawan. (2007), Budaya dan Iklim Organisasi Teori Aplikasi dan Penelitian. Jakarta: Salemba Empat 